\title{
A condenação de 1277, editada por Étienne Tempier, foi o marco inaugural da ciência moderna?
}

\section{Hudson Caike de Andrade Germano*, Fatima Regina Rodrigues Evora.}

\section{Resumo}

Em 1277 o bispo de Paris Étienne Tempier, junto a outros teólogos, redigiu um documento que condenava, em Paris, 219 proposições e argumentos deterministas extraídos ou baseados na filosofia de Aristóteles. Dois comentadores contemporâneos - a saber: Pierre Duhem e Alexandre Koyré - defendem posicionamentos antagônicos no que se refere ao papel dessa Condenação sobre as revoluções científicas dos séculos XIV e XV. Esta pesquisa tem como objetivo se posicionar neste debate, analisando os argumentos de ambos os autores e se há correspondência de suas teses nas obras de John Buridan e Nicolas Oresme, ambos da Escola Nominalista de Paris.

\section{Palavras-chave:}

Condenação, Ciência Moderna, aristotelismo.

\section{Introdução}

$\mathrm{Na}$ Universidade de Paris, no que tange física e cosmologia, os alunos estudavam os tratados naturais de Aristóteles que, a contragosto dos teólogos da Igreja, tratavam os fenômenos da natureza como leis determinadas. Isso significa, segundo os teólogos, que é impossível de se reconhecer a onipotência divina diante das leis que governam o mundo, uma vez que Deus não poderia fazer aquilo que desejasse no universo que criou pois estaria também sujeito à estas leis.

Houve mais de uma tentativa de se impedir o avanço desse aristotelismo em Paris. Entre os anos 1210 e 1215, a Igreja editou decretos que proibiam as leituras públicas ou privadas dos tratados naturais $e$ da Metafísica de Aristóteles, penalizando com a excomunhão aqueles que desobedecessem. Entretanto, muitos anos depois tais medidas foram esquecidas e, em 1255, a universidade reorganizou seu currículo, colocando, novamente, o estudo destes textos.

Como bispo de Paris, Étienne Tempier se viu responsável em deter o avanço das teses aristotélicas. Por isso, em 1270, o bispo condenou vários temas que eram conflitantes entre teólogos e aristotélicos. Não surtindo o efeito desejado, ele reuniu autoridades eclesiásticas e teólogos para redigir um documento que condenasse vários chamados "erros" da ciência da época que conflitavam com aquilo que eles chamavam de natureza divina.

\section{Resultados e Discussão}

Esta pesquisa se propôs a discutir os efeitos da Condenação parisiense de 1277 , editada pelo bispo católico Étienne Tempier, que condenou 219 proposições e argumentos deterministas extraídos ou baseados na filosofia de Aristóteles. O recorte escolhido foram as proposições 34 e 49 as quais dizem, respectivamente: '34 - A causa primeira não poderia fazer vários mundos; 49 - Que Deus não poderia mover os céus com movimento retilíneo. A razão é que 0 vazio permaneceria'1

A discussão inicia-se através de uma passagem do texto Études sur Leonardo Da Vinci, de Pierre Duhem, o qual afirma neste texto:

'Se nós podemos apontar uma data para o nascimento da ciência moderna, nós poderíamos, sem dúvida, escolher o ano de 1277 quando o bispo de Paris solenemente proclamou que vários mundos poderiam existir, e que todo o céu poderia, sem contradição, mover-se com movimento retilíneo'2

Alexandre Koyré, entretanto, defende que o documento editado pelo bispo não teve influência sobre os pensadores e cientistas medievais ou modernos, uma vez que, sendo motivado por razões inteiramente teológicas - pois o objetivo do bispo era defender a onipotência divina de um aristotelismo que é determinista

não teria nenhum efeito sobre cientistas que consideram apenas argumentos científicos nas suas teses.

\section{Conclusão}

O posicionamento de Alexandre Koyré, embora bem estruturado, pode ser facilmente questionado. Ao escrever sobre a possibilidade do mundo mover-se em linha reta, John Buridan cita claramente a Condenação de 1277, demonstrando sua influência sobre sua obra. Ele escreve:

'Mas com respeito ao poder divino foi decidido pelo Bispo Parisiense e pela Universidade de Paris que é um erro afirmar: Deus não pode mover o mundo como um todo e todas as coisas simultaneamente por meio de um movimento retilíneo.'3

Assim, parece-me aceitável que, embora o objetivo do bispo não fosse o de influenciar os pensadores da época a pensar num outro tipo de física e cosmologia diferentes das admitidas naquele tempo, de fato os influenciou, lançando as bases daquilo que hoje conhecemos como ciência moderna.

\section{Agradecimentos}

Agradeço à minha orientadora, prof ${ }^{a}$ Dra. Fátima R. R. Évora, a qual, com sua paciência, compreensão e ajuda tem me ajudado a me tornar um estudante melhor. Agradeço ao CNPq por tornar possível, mesmo em tempos de golpe, o desenvolvimento da pesquisa no Brasil.

TEMPIER, E. Condenações de 1277. Trad. Fátima Évora.

2 DUHEM, P. Études sur Léonard de Vinci, II, p. 412.

${ }^{3}$ BURIDAN, J. Questiones super Libris Quattuor de Caelo et Mundo, I, q XVI. 